\title{
NOT A MIRACLE AFTER ALL... CÔTE D'IVOIRE'S DOWNFALL: FLAWED CIVIL-MILITARY RELATIONS AND MISSED OPPORTUNITIES
}

\author{
Asst. Prof. Boubacar N'Diaye \\ Departments of Political Science and Black Studies \\ The College of Wooster, Ohio, USA
}

\section{Introduction}

Long touted as an island of political stability and (relative) economic prosperity in West Africa, since December 24, 1999, Côte d'Ivoire* has joined the more common category in the sub-region: praetorian states mired in political uncertainty and unending turbulence. Indeed, on September 19, 2002, it came very close to collapsing altogether, a fate very few would dare to predict only a few weeks earlier. This stunning evolution started with the military regime of General Robert Guei, which lasted less than ten months. Eric Nordlinger's definition of praetorianism as "a situation in which military officers [in the case of Africa noncommissioned officers as well] are major or predominant political actors by virtue of

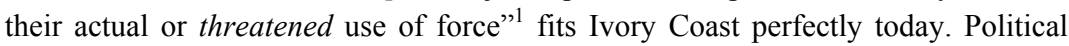
violence has already claimed thousands of victims. As witnessed in the recent resumption of fighting and bloody upheaval, the threat to the country and the entire sub-region has by no means disappeared - despite the Marcoussis and Accra agreements and continued efforts to end the crisis. ${ }^{2}$

Since that faithful Christmas Eve 1999, when the military peremptorily stepped on to the political scene, Cote d'Ivoire has definitely entered a critical era in

\footnotetext{
* By decree dated October 14, 1985, the Ivoirian government decided to name the country "Côte d'Ivoire" and to no longer accept translations of this French name. However, the English translation is still widely used by American writers. "Ivoirian" is the English translation of the French adjective "Ivoirien." This decision revealed the "special" relationship between the country's elites and the French language. I fail to see the point of accepting only one foreign language version of a concept when the overwhelming majority of the country's population does not speak that foreign language. Therefore, I have decided to use the two versions interchangeably.
} 
its civil-military relations (in the broadest conception of this phrase). Early hopes for a speedy normalization were systematically dashed, and even as President Laurent Gbagbo's term ominously nears its end, tangible progress remains elusive in spite of unrelenting efforts on the part of the international community. ${ }^{3}$ Cote d'Ivoire's situation illustrates pointedly Claude Welch, Jr.'s warning that "[t]he first overt seizure of power by the armed forces constitutes the most important shift in civil-military relations... It is a step not readily reversed."4 Furthermore, as too many African states illustrate, once that fateful step is taken, a pernicious "militaryas-a-justifiable-player" mentality seems to permeate the polity, increasing the likelihood of the military becoming a fixture on national political life, one way or the other. This situation begs the questions: How did this one prosperous and reputed stable powerhouse in West Africa take such a turn? What explains that Ivory Coast has moved so quickly from a sure bet for continued civilian (if not necessarily democratic) ruled state to a conclusively praetorian state? An answer to these and related questions will begin to shed some light on this situation.

To the casual observer, all seems to have started on Christmas Eve 1999, when a mutiny of gun toting petty officers and soldiers degenerated into the fullblown coup d'état that toppled President Henri Konan Bedié. The coup, which took most observers by surprise, was remarkable in how easily it unraveled the forty-year old civilian regime. However, as argued elsewhere, ${ }^{5}$ the present situation is the outcome of dynamics in the Ivoirian body politic and, as a derivative, of singular civil military relations concocted since the country's independence in 1960. To understand the intervention of the military and the country's subsequent troubles, it is critical to look beyond the unimaginative policies and even the crass conduct and practices of President Bedié during the last months of his tenure. While these may have precipitated the coup, the roots of the "praetorianization" of Ivoirian politics are deeper and more ancient.

This study is an attempt to answer aspects of the above-mentioned questions. To this end, using an analytical framework centered on the concept of "coup vulnerability," the article first chronicles and analyzes the evolution of the civil-military relations in Ivory Coast since independence, with special focus on how these were handled by the successive heads of state, the turning points in these relations as well as the related behavior of the main actors. It will be argued that the roots of the successful Christmas 1999 coup and its aftermath must be traced to the distinctive and singularly obsessive efforts to prevent coups, and a vexatious unwillingness to seize on numerous opportunities to transform and reorient the security apparatus. Second, the collapse of the military regime, its reasons, and the events that led to it, as well as the dynamics of the current crisis are examined. The 
analysis focuses on the divisions the coup injected in the military, General Guei's miscalculations, and to be blunt, his ineptitude as a leader, as well as the other relevant political considerations. Finally, the still doubtful attempts to turn the page on the still festering imprints of praetorianism, long standing authoritarianism, and the malicious throes of ethnic politics are evaluated.

Before presenting a relevant brief historical background about Cote d'Ivoire, it is useful to outline the analytical framework based on the concept of "coup vulnerability", which is borrowed from N'Diaye. ${ }^{6}$ This analytical framework embraces, integrates, and expands on the classical notion of civilian control of the military developed by scholars such as Samuel Huntington, S.E. Finer, Claude Welch, JR. K. Kemp and C. Hurdlin, and others. ${ }^{7}$ Drawing on the work of these authors it posits that less problematic civil-military relations, that is a willing subordination of the military to civilian political authorities are most likely to obtain in states where the civilian authority is legitimate, the military is professionalized, its autonomy valued, and its expertise and authority over internal affairs recognized and respected. The analytical framework predicts that a state's vulnerability to military intervention in the political process decreases or increases as a function of the extent to which the above state of affairs (as a matter of deliberate policy and behavior) is pursued, or instead, neglected and undermined. Consequently, the evolution of civil-military relations in Cote d'Ivoire is examined considering:

- The extent to which the security apparatus has been professionalized;

- Its degree of autonomy as a whole and in its components (absence of politicization and ethnic or regional manipulation);

- The extent of government legitimacy;

- The military's perception of government legitimacy; and

- The extent of military restiveness.

As the efforts pursued by the various regimes to ward off military intervention strayed from political legitimacy, pursuit of military professionalism and correlated policy actions, it is expected that civil-military relations will breakdown. This is in line with African scholarly assessments of what it will take to democratize African states and to work towards the "twin principles of military expertise and civil supremacy". 8 Of course, military professionalism and autonomy are not a panacea and some scholars, including Rebecca Schiff, have found this approach problematic in dealing with civil-military relations in developing countries. ${ }^{9}$ 


\section{Historical background}

A former French colony in West Africa, Cote d'Ivoire became an independent state on August 7, 1960 after centuries of French colonial presence. Like most African states, an extreme ethnic and religious diversity characterize its approximately 14 million people. ${ }^{10}$ Contrary to most other colonies, independence was not the objective of Ivory Coast's political leaders in the late 1950s. Independence came only after the failure of the "Communauté Franco-Africaine" set up in the late 1950s to salvage France's crumbling colonial empire in Africa. ${ }^{11}$ Even after independence, Ivory Coast kept unique relations with France, thanks to the imposing personality of Felix Houphouet-Boigny, who until his death on December 7, 1993, was for almost 34 years Ivory Coast's only President. As Aristide Zolberg documents, Houphouet-Boigny along with the party he created, the Parti Démocratique de Côte D'Ivoire (PDCI), was the principal architect of every major policy orientation and decision of the Ivory Coast over the last half century. ${ }^{12}$

Under his leadership Ivory Coast pursued a resolutely pro-Western, capitalist economic strategy and foreign policy. The country experienced a rapid economic growth throughout the 1960s and 1970s. It also stood out in the West African sub-region for its political stability. Houphouet-Boigny also enjoyed a reputation of man of wisdom and peace. ${ }^{13}$ This image, often propped up by the French (and western) media, was assiduously cultivated by calculated, often beneficent or magnanimous grand gestures in domestic, sub-regional or international politics. It was also echoed in the state-controlled media and by a legion of flattering journalists and writers.

The deepening economic crisis of the 1980s gave rise to ever more pressing demands for radical changes in the macroeconomic orientation and distributive policies. As in other states of the region, an emboldened political opposition vociferously demanded the end of the PDCI's monopoly on power. ${ }^{14}$ After much resistance and violence, multiparty elections and other reforms were introduced in 1990, not coincidentally after the La Baule France-Africa Summit. On December 9, 1993, two days after Houphout-Boigny's death, when National Assembly President Henri Konan Bedié was sworn in as the head of state in accordance with article 11 of the Constitution, the face of Ivory Coast had changed beyond recognition. And yet, the only seemingly immutable variable was the unique relationship, often characterized as neocolonial, independent Ivory Coast has developed and maintained with France. Nowhere has that relationship been more consequential than in the area of regime maintenance (in the African context, this meant mainly coup prevention in addition to reassuring internal and external 
security guarantees). Consequently, a meaningful analysis of the successful overthrow of the Bedié government on Christmas Eve 1999, manifestly against the tide of worldwide democratization and demilitarization, must start with the long running, entangled Franco-Ivoirian efforts to prevent precisely that outcome. To reiterate, the author's contention is that while Bedié's political recklessness precipitated his overthrow by the soldiers, ultimately, reckless civilian control strategies, broadly construed, are the root-cause of the military intervention in the political process in Cote d'Ivoire.

\section{Regime stability: instruments and cost}

\section{The set-up}

Before examining the deeply flawed security sector arrangement and attendant coup prevention strategies implemented by the post-colonial regime in Cote d'Ivoire, it is useful to look at the Ivoirian security apparatus and its role in the stability of the Houphouet-Boigny regime. It was created from the remnants of the colonial army in 1961 by the 61-209 Law which organized national defense following the French government's 1960 plan raisonnable establishing armies in its former colonies. ${ }^{15}$ Until they were split by the September 2002 rebellion, the International Institute for Strategic Studies estimated that the armed forces of Cote d'Ivoire stood at $13,900 .{ }^{16}$ The largest service being the army $(6,800)$, followed by paramilitary bodies the gendarmerie $(4,400)$, and the presidential guards $(1,100)$. The Navy (900) and Airforce (700) are the smallest services. In addition, there are 12,000 reservists, 1,500 PDCI militia members and, of course, the intelligence services attached to the presidency, the ministry of security and ministry of defense. After assuming the presidency, President Bedié, created the National Security Council, modeled on the US institution of the same name and appointed trusted gendarmerie General Joseph Tanny to head it. As will be discussed later, France, the former colonial power and closest ally, played a major role in the set-up and training of these forces. In a West-African sub-region reputed for its countless coups, military regimes, and recurrent turmoil, Cote d'Ivoire enjoyed, until the 1990s, a remarkable, if relative, stability. However, beyond the personal leadership qualities often attributed to Houphouet-Boigny and the remarkable economic growth the country experienced in the 1960s, 1970s, and early 1980s the much overrated exceptionality of Cote d'Ivoire is better analyzed in light of the policies to consolidate the post-colonial regime starting immediately after independence. As David Goldsworthy has noted perceptively, "the dominant long-lived civilian leaders of Africa do not leave their relations with the soldiers either to chance, or to the growth rates, or to the broader working of structural variables." 17 
After the failure of the joint defense structure France had envisioned as a part of a scheme to retain close ties with its soon to be former colonies in Africa, the overwhelming majority of newly independent states entered into a series of defense agreements with France. Generally, the defense agreements provide for the set up, training and equipping of African militaries and security services, and the presence of French (military and civilian) technical advisers. They also enable African states to call on France to ensure their external and internal security (reestablishing law and order), ${ }^{18}$ including the prevention of "putsches, and other coups d'état." ${ }^{, 19}$ For its part, Cote d'Ivoire, signed a defense agreement on April 24, 1961. This agreement provides for the permanent basing of troops, has ultra-secret clauses, and has not been renegotiated for nearly thirty years. ${ }^{20}$ The importance of Cote d'Ivoire to France was unmistakable. Along with Senegal, it was singled out by General De Gaulle as countries in which France would intervene if necessary. ${ }^{21}$ Danielle Domergue-Cloarec, has argued that some of the defense agreements signed between France and its former colonies, contain secret clauses to guarantee the personal safety of heads of state and their families. ${ }^{22}$

Given Houphouet-Boigny's central role in the post-colonial political and security arrangements, it is reasonable to assume that such a secret clause existed with Ivory Coast. Thus, a noticeable characteristic of these accords is that, as Chester Crocker noted, they "imply a commitment to regimes, as opposed to states". ${ }^{23}$ It is also useful to add that because of its origins and the deep imprint of its French designers and sponsors, the Ivoirian security sector inherited the features, philosophies and structures of France's conception of a state security. This essentially means a tradition of the army as "la grande muette" (the great mute one), that is, strictly apolitical, republican, loyal to the 'state', in charge of 'national defense' under the leadership of a head of state, who is 'chief of the armies' with extensive formal and discretionary prerogatives in matters of state security. This also means the Cote d'Ivoire did not have a unified notion of a holistic "security sector" as currently understood in the literature.

The preceding context constituted the setting for the civil-military relations that developed over the forty years the post-colonial PDCI regime lasted in Cote d'Ivoire. Finally, while inheriting wholesale the security and military tenets and assumption of the former colonial master is not unique to Ivory Coast, this can arguably be considered the first missed opportunity to design a security sector based on a different conception of security for the state and the people. Instead, the security apparatus was used to guarantee and perpetuate Houphouet-Boigny's and the PDCI's power using a variety of nefarious strategies and tactics. These very strategies were to lead to the 1999 coup. 


\section{Coup prevention strategies, seed of the 1999 coup}

In the context of rampant praetorianism in West Africa, ideological rivalries with its neighbor (mostly Guinea under Sékou Touré and Ghana under Kwame Nkrumah), the regime of Houphouet-Boigny could not feel too secure. In such conditions, the preservation of the regime assumes a paramount importance. Observers of civil-military relations in Africa have noted that the cornerstone of the strategies of the Ivoirian regime to retain power has been the continued presence of French troops and military advisors. ${ }^{24}$ While this was indeed the primary strategy, the measures taken to insure that Cote d'Ivoire remained coup free also include shrewd secondary strategies to prevent the military from taking power. Finally, these flawed civil-military relations in the narrow sense sowed the seeds of the December 24, 1999 coup, as will be demonstrated. Other policies, particularly the total disregard to the most basic norms of democracy and the corrupt management of the economy must also be briefly examined, as these are germane to the civilmilitary relations and security in general.

\section{The French military presence}

Decades ago, Ruth First observed that Houphouet-Boigny's close relationship with France was "the soundest insurance against a successful coup" ${ }^{25}$ There is no doubt that the PDCI regime owes most of its longevity to the presence of French troops and French military assistants at all levels in the ranks of the Ivoirian military. This "external guarantee strategy" ${ }^{26}$ which consisted (and resulted) in the deterrent stationing of hundreds of French Marines near Abidjan, the presence of French military advisors, a sustained program of training for the Ivoirian military, and a significant reduction of defense expenditure, had also fatal flaws. Along with the other equally flawed (but somehow secondary) regime maintenance schemes, the strategies undermined the professionalization, autonomy or political insulation of the military. Combined, these strategies further heightened the military's realization of the low legitimacy of the political system and the regime. The evidence suggests that it is the alienation of the Ivoirian military, its politicization and (the resulting) long history of restiveness that culminated in the Christmas Eve coup.

Since the independence of Côte d'Ivoire France has constantly maintained hundreds of marines on its military base of Port-Bouet near Abidjan. The number of these troops steadily increased over the years, no doubt, signaling a strengthening of the French commitment to the survival of the Ivoirian regime. In 1999, even as the coup was under way, French troops numbered nearly $600 .^{27}$ In addition to these readily available troops, France could airlift within hours its domestically based Force d'Action Rapide (FAR) to any trouble spot in Africa. ${ }^{28}$ While in power, 
Houphouet-Boigny left no doubt that he would not hesitate to call on France to help him retain power. In 1971 French troops intervened to put down a rebellion by the Bete, an ethnic group traditionally opposed to the Baoule (Houphouet-Boigny's ethnic group). ${ }^{29}$ In 1990, in the face of a combined civilian and military threat, the President again solicited French intervention (though to no avail this time). Indeed, until 1999 (for reasons to be discussed later), French's military power was ready to see to it that, should the need arise, any coup attempts (at least one it did not approve of) failed. Pascal K. Teya has argued that French troops used demonstrative maneuvers to deter and dissuade potential opponents from even attempting a coup, often injuring the patriotic sentiments of the Ivoirian military. ${ }^{30}$

The presence of French military advisors was another dimension of the strategies of the Ivoirian regime to prevent coups. For years, until it was surpassed by Madagascar, Cote d'Ivoire had constantly had the highest concentration of French nationals in Africa. Up until the 1970s, various high level civil servants, often in sensitive positions, including the president's Chief of Staff, were French citizens. Nowhere has the presence of French nationals been as consequential as in the military. In the efforts of the Ivoirian and French governments to prevent coups, these military assistants are an "even more important army" than the regular French troops. ${ }^{31}$ A compilation from various sources indicates that the number of these military advisors drastically dropped from 248 in 1965 to 111 in 1980, and remained roughly constant at about seventy in the mid-1980s. ${ }^{32}$ The decline is more noticeable after 1980 when anti-French sentiments ran high and the close ties with France were increasingly criticized as neo-colonial. More than a change in the strategy, this decline most likely reflected the necessity for the Ivoirian government to decrease the visibility of French military advisors. Evidently, because of their access to intelligence, these advisors' main role was to ensure that nothing France did not like happened in Côte d'Ivoire.

\section{Cooptation, manipulation, and politicization of the military}

While Houphouet-Boigny, and later his successor Henri Konan-Bedié relied heavily on the close political and military ties with France to ward-off military intervention, they have also pursued other strategies to further reduce the likelihood of a military takeover. These flawed schemes consisted, among other measures, in the ethnic and political manipulation of the military, the co-optation of officers in the political and administrative ruling circles and spoil system, and the exploitation of inter-service rivalries. All of this also contributed to the ultimate overthrow of the regime. 
Houphouet-Boigny was keen to integrate military officers in the machinery of the PDCI regime. For instance, more than 30 per cent of the prefects "who exercise significant powers" in their administrative districts were members of the military; the objective, more or less explicit, was to lessen the risk of military intervention. ${ }^{33}$ The petty officer origin of the 1999 coup seems to give credence to Teya's analysis, in the same vein, that the top brass of the Ivoirian military was cleverly compromised by the regime in the mismanagement of the national economy and in politics in order to neutralize it. ${ }^{34}$ To give the military a stake in the regime, high-ranking officers were even brought into the government in 1974. According to Claude Welch, Jr., Houphouet-Boigny made "political reliability ... the dominant criterion for promotion" in the military. ${ }^{35}$ Other cooptation and manipulation measures were evident. Shielded from the harsh belt-tightening measures of the 1980s, the military was indeed "well treated" economically. ${ }^{36}$ Additionally, military officers were put in charge of parastatals and given the opportunity, indeed encouraged, to enrich themselves illegally. When for some reason top officers become unreliable, they are given positions in state-owned companies or in diplomatic missions to distance them from active service.

The ethnic manipulation of the military was yet another alarming scheme the civilian regime employed to prevent coups. In the early years of independence, Houphouet-Boigny took advantage of a (never proven) "conspiracy" to overthrow his regime to shrewdly disarm the army, fragment and entirely reconfigure the ethnic make-up of the Ivoirian military. ${ }^{37}$ A critical element of this re-structuring has been the creation of a 3,000 person strong PDCI-controlled militia (the presidential guard) made-up exclusively of Baoule, the President's ethnic group. ${ }^{38}$ Another indication of this approach has been Houphouet-Boigny's heavy use of what Howard William has called "a system of ethnic quotas" as an instrument of governance, ${ }^{39}$ which he extended to high-ranking officers as well. In 1982, he had a group of high-ranking Bete officers publicly express their support for him (to dissociate themselves from a growing opposition with ethnic overtones). ${ }^{40}$

The military was manipulated in others ways as well. In 1990, with his power weakened by pro-democracy movements and political parties, a physically and politically weakened Houphouet-Boigny called on the army to brutally repress his opposition. None other than Robert Guei, the future junta leader (then a colonel) was charged with carrying out that mission. Characteristically, Houphouet-Boigny is said to have promised to "fill up [Guei's] pockets with money". ${ }^{41}$ On the eve of the 1995 presidential election, for selfish reasons, President Bedié continued essentially the same approach. He manipulated the inter-service rivalries by playing off the army against the gendarmerie and got rid of General Robert Guei then the 
Joint Chief of Staff for apparently requesting written orders to prepare to use the army again Bedié's opponents in the 1995 elections. ${ }^{42}$

\section{Effects of the coup prevention strategies}

Obviously, the combined effect of the strategies implemented by the PDCI regime has been to keep Cote d'Ivoire coup free for nearly forty years. As the Christmas Eve coup was to stunningly demonstrate, however, these same strategies contained the seeds of the undoing of the civilian regime. In effect, these strategies had grave implications and consequences on the political system as a whole and on civil-military relations specifically. First, the survival of the regime rested not on healthy, sound foundations but on the will of the French government to save it. Second, the various manipulations and machinations sapped the military's professional corporate self-image, and heightened its political and social awareness of the flaws of the system. They made elements within the military realize that not only was the regime's claim to legitimacy tenuous, but that just as force helped it to survive, force could undo it. Third, the frequent uses of the army against the opposition politicized the military even more dramatically. The military came to see itself as a bona fide political player. This increased the likelihood of its intervention in the political arena, only on its own behalf, for its own corporate interests, not to save the regime one more time. Finally, the disastrous management of the affairs of the country, the neglect of the needs of the Ivoirian people, all important dimensions of civil-military relations broadly construed, did nothing to legitimize or consolidate the post-colonial regime.

A closer look at the implication of these overall strategies will help explain this outcome. The web of economic, political, military and cultural relations between France and the Ivory Coast has been described as an illustration of French neo-colonialism. ${ }^{43}$ Edouard Bustin has forcefully argued that in the domain of civilmilitary relations in particular, African states are ultimately the losers in the neocolonial arrangements. First, the defense agreements typically vest in the French President the ultimate decision to intervene, undermining national sovereignty, and giving the protégé regime much to worry about. For example, in a blatant effort to pressure Houphouet-Boigny into abiding by the La Baule summit dictate (that African states should accept multiparty politics), France ignored his request and refused to intervene to put down a military mutiny in June 1990. This uncertainty did not promote civil-military stability. It is indeed dangerous to protégé regimes, for France has been known to ease out presidents she can no longer depend on as in Cameroon and Niger. ${ }^{44}$ As will be discussed below, this scenario is, to some extent, what seems to have happened in December 1999. 
Second, the neocolonial arrangement inherent in the reliance on an external guarantor can lead to the perverse effect of military officers frantically cultivating self-serving relations with the French military authorities and be willing to carry out coups on their behalf. This confuses the military elite by giving them mixed loyalties. The officers know that any move against the regime is likely to be detected in time or crushed by the French military. At the same time, they must remain distant enough from the same regime should it become doomed. They will therefore display insincere loyalty to the regime. Typical examples are the French ousted Jean Bedel Bokassa in the Central African Republic and Hissen Habré in Chad, both of whom were installed by France but subsequently embarrassed or defied by their protector. The cozy relations which apparently existed between General Guei and the French military establishment was made evident in the former French army Chief of Staff, retired General Jeannou Lacaze's efforts to help him retain power in 2000. In addition, As Chipman has stressed, the presence of French military advisors perversely entrusts French nationals to sensitive positions in African militaries and gives them access to information they can use to influence directly and decisively the course of domestic events. ${ }^{45}$ This cannot but affect negatively the morale and possibly injure the sense of institutional pride of African militaries.

Other implications and effects of the coup prevention schemes concocted by Presidents Houphouet-Boigny and Bedié lead to the inescapable conclusion that they also contributed to the demise of the civilian regime. One of the most insidious effects of their policies was that, instead of eliminating military restiveness and instilling civilian supremacy in the military, they produced the opposite. While the Ivoirian military succeeded in displacing the civilian regime only in the 1999 coup, it had a long history of various forms of intervention in the political process, however. One of these forms was coup attempts and conspiracies. Already in 1962 and 1963, in 1973, and in 1980, groups in the Ivoirian military conspired, and in some instances attempted, to overthrow the government. ${ }^{46}$ As recently as in the 1990 s, conspiracies fomented by officers of the Ivoirian military were uncovered. ${ }^{47}$

Other forms of military interference in the political process were mutinies and other forms of overt political insubordination. In 1991, members of the military went on strike demanding higher wages and some soldiers even briefly occupied a radio station. One year earlier, soldiers occupied Abidjan airport. Others roamed the streets at night and engaged in acts of banditry. ${ }^{48}$ In April 1990, in conditions very similar to those that eventually led to the successful coup, President Houphouet-Boigny was forced to meet with mutineers complaining against their living and service conditions. ${ }^{49}$ 
A third form of interference of the military in the political arena, though not at the initiative of military, was its zealous repression of political opponents. In the 1970s and 1980s, and again in the 1990s, both Houphouet-Boigny and Bedié used the military to suppress their political opposition. ${ }^{50}$ In 1971, for example, the army, along with French troops, participated in the massacre of members of the Bete ethnic group accused of separatism and opposition to the Houphouet-Boigny regime. $^{51}$ In 1991, during sustained pro-democracy demonstrations, the military brutally repressed university students. The repression was so vicious that even the Prime Minister considered it "revolting." As recently as 1995, the military was used against political opposition during the succession struggle. In the city of Gagnoa, several opponents were killed. The politicization of the Ivoirian military was already deepened by charging it with the "civic and moral education" of union members and students who were leading the opposition in the late 1980s. It was little wonder that during the succession struggle between Henri Konan Bedié and Alassane Dramane Ouattara, Houphouet-Boigny's last Prime Minister, the army seemed to align itself against President Bedié even though he eventually prevailed in the contest. ${ }^{52}$ While this version is not unanimously agreed to, it is certain that the military through none other than Robert Guei did get involved in the succession dispute.

In the end, it is evident that no analysis of the Christmas Eve 1999 coup can be complete without a discussion of the policies Houphouet-Boigny and indeed Bedié pursued in the overall management of the country. These are germane to any analysis of civil-military relations, as invariably they constitute the backdrop of the military intervention and are typically used to justify it. As will be seen later, the Ivoirian coup was not exception. Indeed these policies and attitudes also contributed further to digging the grave of the PDCI regime.

The evidence overwhelmingly indicates that the affairs of the state were conducted with a high degree of mismanagement and corruption. Many authors attribute the economic crisis that befell Ivory Coast to the wasteful, corrupt neopatrimonial practices associated with Houphouet-Boigny. ${ }^{53}$ He once publicly urged his ministers to enrich themselves, and most of his ministers were found to be "self-serving and corrupt". ${ }^{54}$ This partially explains why as much as 130 billion CFA Francs were annually embezzled and taken out of the country, and the countless multi-billion CFA Francs financial scandals involving governmental elites, including Bedié. ${ }^{55}$ The actions taken by the soldiers throughout the 1990s, including the fatal blow to the regime were justified by the disparities between their destitute economic conditions contrasted with those of the elites. 
Politically, for years, through undemocratic means and an elaborate clientelist scheme, Houphouet-Boigny managed to enlist the loyalty and devotion of large segments of the intellectuals and business classes. He used the Party Démocratique de Côte d'Ivoire (PDCI) and its organs to maintain a firm control over the state apparatus. Only in 1990 when violent opposition demonstrations threatened the very existence of the regime was Houphouet-Boigny forced to introduce multi-party elections. While the introduction of multi-partyism and other trappings of democracy constituted a step toward more responsiveness and legitimacy, it did not guarantee free and fair elections or democratic practices. Immediately after succeeding Houphouet-Boigny, with the tacit but firm support of France, Bedié displayed unmistakable authoritarian tendencies. ${ }^{56}$ The multi-party elections of 1990 and 1995 were no more free and fair than the previous elections when the PDCI monopolized political life. In this respect, Konan Bedié seems to have replaced the (mostly) co-optation and subtle repression strategies characteristic of the pre-1990 period with heavy-handed, crass repression. Despite some limited progress since the 1990 reforms, Ivory Coast's record of respect for democratic rights and freedoms, measured by diverse organizations and observers, tends to indicate that these rights were often violated. Each Amnesty International annual report since 1991 describes the detention, mistreatment (including torture) and even killing of hundreds of political opponents and several journalists. In 1991, several members of the military were detained and tortured after an alleged coup attempt, ${ }^{57}$ and significantly, in 1997, at least 10 members of the military figured among those detained and mistreated. ${ }^{58}$

\section{The missed opportunities}

The wave of democratization and demilitarization of African politics in the 1990s notwithstanding, the stage was set for the military takeover. Again, while a series of fateful events and the outright foolish behavior and attitude of President Bedié were precipitants for the coup, the civil-military relations built around flawed coup prevention strategies and other related policies are seemingly its root causes. In general, since the set up of its military in 1961, numerous opportunities to model a security apparatus that would entrench a political system based on values of democracy, legitimate state and individual security, were missed. The reorganization of the armed forces after the alleged 1963 coup was one such opportunity. Instead, Houphouet-Boigny created an all-Baoule presidential guard, and a militia as the armed arm of the PDCI, and left untouched the overall structure of the security architecture centered on the presence of French troops and military advisors as security guarantors. 
Another opportunity presented itself in 1990 when the president was forced to negotiate with mutineers about a wide range of issues including organizational and inter-service concerns. The most compelling opportunity to reform the security sector came when President Bedié assumed power in a constitutionally prescribed manner in 1993. Aside from the creation of the National Security Council, no serious reform was undertaken. In fact, to further ward off any military intervention, Bedié chose to exacerbate the rivalries between the services, playing off the army against the gendarmerie, more specifically, the Chief of the latter, General Joseph Tanny, against General Robert Guei, then Chief of the Army. It was evident that the extensive reassignment of officers in the various commands shortly after the 1995 elections was an indication that the situation in the security sector was a matter of concern for him. This pattern of Ivoirian heads of state's unwillingness to tackle what was evidently a serious situation in the security sector and civil-military relations was to continue even after the Christmas Eve coup. That coup, evidently, was both the irrefutable proof, both of the failure of old policies and strategies, and the security sector's dire need of serious overhaul. Its occurrence seems to support the 'coup vulnerability' hypothesis.

\section{The coup and its aftermath}

With their decision to oust Henri Konan Bedié and to constitute a military junta, the Comité National de Salut Public (CNSP), to run the country, the Ivoirian military ushered in a new era of civil-military relations in Cote d'Ivoire. The success of a group of non-commissioned officers in displacing without bloodshed and almost effortlessly one of the longest running civilian regimes on the continent was an eloquent testimony to the utter failure of the coup prevention strategies and overall regime sustaining policies of the PDCI and its leaders. In particular it illustrated the failure of the external guarantor strategy and officer corps manipulation/cooptation schemes to anticipate two critical phenomena. First, increasingly, military interventions in African political processes are spearheaded by commissioned and non-commissioned junior officers, not the top brass. President Bedié's lament that all his generals had fled as the coup unfolded, ${ }^{59}$ is instructive in this regard. Second, as the 1994 coup in The Gambia, the failed coup in Guinea in 1996, and more recently the failed coup in Burundi (2001) and Guinea Bissau (2004) illustrate, these military interventions are no longer the planned, by-the-book, "full-blown" coups d'état of old, but can, in the heat of mutinous actions, achieve the same outcome. Though there seems to be evidence that other more 'typical' coups may have been in preparation, ${ }^{60}$ what started as a mutiny of soldiers to call attention to their precarious conditions and to the manifestly deteriorated political situation in the country, rapidly escalated into the ouster of the head of state. 
The coup also highlighted the fatal mistakes President Bedié made in not carrying out an overhaul of the security sector, despite the window of opportunity his coming to power presented. In this regard the coup can be seen as a patent failure of leadership as well as the bankruptcy of the security apparatus on which Bedié has artlessly grown dependent to keep his opposition at bay. Typical of his poor leadership savvy, even as he leaned more and more heavily on his security system to maintain power, President Bedié consistently ignored the insistent warnings of his French backers of growing discontent and restlessness in the military. French intelligence services had in effect specifically alerted him repeatedly to this situation and of the potential replication of restiveness and insubordination witnessed in other African states following the return of peacekeeping contingents and urged him, to no avail, to take counter measures. ${ }^{61}$

According to General Robert Guei, who was brought out of retirement by the mutineers to lead them, in a statement on December 24, 1999, the reasons for the coup were twofold:

There are problems which are strictly of military order which concern the restoration of their dignity; that is, the improvement of their equipment, salary increases and some problems peculiar to the military profession... The other problems are political, since they called for the unconditional release of elements currently imprisoned at the Abidjan Central Prison for political reasons.

During his meeting with the mutineers, Bedié used foul language and displayed an arrogant and insulting attitude, in reaction to which it was decided to depose him. ${ }^{62}$ Just two days earlier, in a speech to the nation, a defiant Bedié had stubbornly refused to heed the insistent calls for moderation of friends in the international community. He had rejected pleas to free the jailed militants of the main opposition party, the Rassemblement Des Republicains (RDR) and to lift the ban imposed on Alassane Dramane Ouattara, the former Prime Minister. Ouattara had been excluded from the upcoming presidential election under the pretext that he was not a citizen of Côte d'Ivoire. As if nothing could ever change in the basic nature of his relations with France, Bedié relied almost blindly on the French military umbrella. This attitude blinded him to noticeable changes in French policies on military intervention to rescue friendly regimes, in general. It certainly blinded him to unmistakable signals that the French authorities (in a stalemated socialist government/rightwing president-cohabitation-situation) had grown irritated by his drift toward autocratic rule, in particular. 
French "preoccupation" with his handling of his political opponents (particularly the disenfranchisement of Alassane Ouattara) and the injection of virulent xenophobia in Ivoirian politics, was expressed in the form of polite public pronouncements as well as blunt private warnings. He had forgotten that already in 1990, on the wake of promulgation of the La Baule doctrine, President François Mitterrand had stunned Houphouet-Boigny by refusing to intervene against mutineers who had occupied the Abidjan airport. Furthermore, in 1997, France's Foreign Minister specifically told the (former) Organization of African Unity (OAU) that henceforth his country refused to "be dragged in internal conflicts" in Africa. ${ }^{63}$ Finally, his almost defiant mismanagement of the economy brought the country very close to bankruptcy and alienated the European Union (EU), the World Bank, and International Monetary Fund (IMF). The embezzlement of billions of EU aid was also still fresh in the news.

After a moment of confusion and a futile attempt to reverse the course of events, Bedié and his family fled the country with the help of France after seeking refuge in the French embassy in a strange twist of irony. He had appealed directly on a French radio to loyalist forces and the general population to resist the coup. On the contrary, the population and the political class seemed to have almost unanimously been relieved to see the political impasse come to such a decisive, if unexpected, end. The statements of General Guei were reassuring enough as he declared that he had no ambition to remain in power and that the soldiers have taken power to "clean up the house" and that, as soon as this is done, they will abandon power. ${ }^{64}$

The shock and later the protestations of the international community, were somehow muted by the collective sigh of relief and even jubilation which emanated from the Ivoirian people and its political class. Acceptance of the fait accompli was soon evident even as governments and international organizations called for a speedy transition to constitutional rule. This was particularly true of the OAU, which had, a year earlier decided to refuse admission to any government resulting from a coup d'état. After the initial puzzle as to why French troops stationed in Port-Bouet didn't intervene to save Bedié's regime, the real question turned to how long the military would stay in power, and what political situation is likely to emerge after the transition period?

As the military junta and those in the political class who objectively benefited from the ouster of Bedié, started to prepare for the transition to new institutions and rules of the game, few foresaw the dangerous course Cote d'Ivoire 
was about to embark on. For, however welcome and even salutary it may seem sometimes, the intervention of the military in the political arena invariably brings about an array of uncertainties and dangers. Not only is the potential for deep divisions within the military a very likely outcome with a chain of coups and counter-coups, but the potential for violence as the preferred means to solve contradictions increases sharply. Although it lasted less than a year, the experience of military rule in Côte d'Ivoire brought all the possible twists and turns that can be expected from an inexperienced and divided military institution purporting to set up a democracy for a country facing daunting challenges. This deadly mix produced the most startling military regime interlude in African modern history. Its main ingredients consisted of General Guei's awakened personal political ambition, his inept leadership, the effects of the inherent tensions of the hybrid role thrust on the military as institution and as government, and finally, the effects of the political manipulation of ethnicity, regionalism, and religion in the Ivoirian body politic.

\section{The military interlude}

If for nearly forty years, power in Ivory Cost was certainly civilian as opposed to military, it was definitely not democratic. As Robin Luckham has stated, there is more than a nuance in the distinction. ${ }^{65}$ Given the circumstances that led to the current crisis, the military interlude failed miserably to usher in a democratic civilian regime, if this ever was its objective. In many respects President Laurent Gbagbo, just as Presidents Houphouet-Boigny and Bedié before him, does not owe his position to the express will of the Ivoirian people. When the unsolicited "military experiment" Côte d'Ivoire underwent started, the odds seemed good enough. A political impasse was finally unblocked, the military leader dragged apparently against his will from retirement unambiguously stated that he had no interest in power and that, once an orderly transition was completed the military would withdraw to its barracks. The euphoria in the population and in the overwhelming majority of the political class rapidly vanished when General Guei, without ever stating his intentions until the very last constitutionally mandated moment, revealed his true face.

His intention to use the transition to fulfill a suddenly awakened presidential ambition became clear when, after decrying in his first pronouncements the political blunder Bedié had committed in injecting the poisonous concept of "Ivoirite" in Ivoirian politics, he embraced it and wrote it in the new constitution. ${ }^{66}$ Next, came the elaborate use of the judiciary to eliminate cumbersome opponents from running (another Bedié antic), and finally, in the face of electoral defeat by a "light weight" candidate, the blatant attempt to perpetrate a "coup in a coup" by canceling the election altogether and proclaim himself president. Very few foresaw 
this evolution although, early in the transition, General Guei had started to wrap himself in the mantel of a still much revered Houphouet-Boigny. In hindsight, given his thorough cooptation in the political circles of the PDCI, between 1990 and 1997 , when he was unceremoniously forced into retirement by Bedié, the opportunity to take his revenge on the political system and on Bedié himself would have been too tempting to let slip by. An element of what can be called the "De Gaulle complex" may have also played a role in his decision to want to continue in office. ${ }^{67}$

His decision may as well be simply the result of the corrupting influence of power. Whatever motivated it, this decision proved to be an unmitigated disaster for Cote d'Ivoire. It nearly pulled down the entire sub-region into chaos and violence. When this sad episode was all over, the country laid in economic shambles. It was badly divided and, due to centrifugal forces of all sorts in an advanced state of decomposition. The same could be said of the entire security sector as well. Security forces killed hundreds of peoples, chaos loomed, and Ivory Coast was no closer to democratic civilian control or real political stability than it was on December 24, 1999. Arguably, it was far worse off. Despite the adoption of a new constitution, the post-colonial political system and the elite philosophy that underpinned it was largely untouched. Understandably, the security sector was also left essentially intact.

While the military institution was not a model of unity when the coup took place, partly due to divisive tactics by both Houphouet-Boigny and Bedié, the experience of ruling the country deepened its many cleavages. Very early in the military administration the gendarmerie, believed to be more loyal to Bedié, was pitted against the army. Similarly, northern high-ranking Muslim officers, particularly Generals Lassana Palenfo and Abdoulaye Coulibaly, respectively second and third ranking members of the CNSP and putatively close to Alassane Ouattara, seemed to be at odds with General Guei and other southern or western Christian officers in the CNPS. To complicate this situation further, the same corporatist and materialistic-cum-political reasons that motivated the coup in the first place, led to a large-scale mutiny on July 4, and 5, 2000. In addition to asking millions of CFA Francs, the mutineers demanded no less than a pledge by General Guei that he would not run. ${ }^{68}$

After fierce fighting quieted down, General Guei needed all the dealmaking skills he could muster (and sweeping promises of material reward) to end the mutiny. Evidently, the 40 per cent increase of the soldiers' salaries the junta had decreed earlier ${ }^{69}$ was apparently not enough to assuage the military's assertive claims to a bigger slice of the fast shrinking financial pie. It was, however, all but 
certain that Guei's candidacy to the presidency was an important reason for the restiveness in the ranks. It was soon evident that a widening rift existed in the ruling junta as well. The September 17, 2000 attack on General Guei's residence, whether real or faked, was another manifestation of the deep divisions in the military. As a direct result of this attack, Generals Palenfo and Coulibaly, fearing for their safety, had to take refuge in the Nigerian embassy to escape arrest. As their open letter to Guei from their hideout revealed, the main reason for the rift was Guei's decision to run for the presidency and their opposition to that decision. ${ }^{70}$ Their trial under the Gbagbo regime confirms their allegations, as Guei through an envoy, urged the military tribunal to release them "because they had no hand in the attack". 71

These developments confirm that it is indeed a difficult gamble for the military, by definition a non-democratic, hierarchical, conspiracy-prone institution, to be in charge of transforming an authoritarian political system into a real democracy. It is not sure, however, that even a unified and efficient military would have been able to carry out successfully this task after forty years of PDCI rule. The task was made singularly more difficult after Bedié's divisive policies fragmented so deeply the political elite and, generally, the Ivoirian people. Furthermore, there are objective social and political problems associated with the dozens of ethnic groups comprising Cote d'Ivoire and the fact that nearly one third of its population are immigrants from neighboring states. In addition, Ivory Coast has also had a history of economic and political disenfranchisement of the northern, predominantly Muslim part of the country by the predominantly Christian southern and western elites. $^{72}$

After the succession struggle in which Bedié prevailed, a split in the PDCI led to the creation of the RDR (Rassemblement Des Republicains) around Alassane Ouattara, Houphouet-Boigny's only Prime Minister, and other disgruntled PDCI militants. While the 2001 municipal elections revealed its solid urban and national implementation, the RDR is widely believed to represent mainly northerners. The strength of the RDR and, over the last decade, the demographic shift in Cote d'Ivoire in favor of northerners, has, for the first time, made it possible for a northerner, namely Ouattara, to have a definite chance of being elected head of state. This prospect, and its potential for upsetting the economic, ethnic, religious, and political arrangement crafted by the PDCI regime, seems to have been at the heart of the efforts by Bedié and his circle to prevent Ouattara from running. As Generals Palenfo's and Coulibaly's letter suggests, these considerations may have also influenced Guei's advisors ${ }^{73}$ in getting him to bar Ouattara one more time, and to run for the presidency himself. ${ }^{74}$ 
A Supreme Court Guei had made sure to pack with his cronies found legal reasons to eliminate any candidate susceptible to make the race competitive for the Junta leader. The former President Bedié then in exile in France, Emile Constant Bombet, his former senior minister, Mohamed Lamine Fadiga, another former minister, were all disqualified for one reason or another. ${ }^{75}$ Guei also sabotaged the various initiatives of the international community, singularly the OAU's efforts, to find an acceptable solution to a situation with potentially grave implications for the entire West African Sub-region. ${ }^{76}$ Nothing was to stop his plans to remain head of state. However, these plans failed, when, on October 22, election day, the electorate reported massively its votes on Laurent Gbagbo, the leader of the Front Patriotique Ivoirien (FPI), a long time opponent to the PDCI regime who, like Guei, is from western Cote d'Ivoire. He too seemed to have accepted the "Ivoirite" thesis, if only tactically in order to eliminate Ouattara. It is widely believed that Gbagbo's candidacy was validated by the Guei controlled Supreme Court only because he was thought to be weak enough to allow and make more legitimate a first round victory for Guei. To Laurent Gbagbo's credit, he called on his supporters to refuse to accept Guei's electoral putsch and to repeat the Yugoslav scenario that drove Slobodan Milosevic from power only a few weeks earlier. In so doing, he succeed, in what was referred to as the 'boulevard coup,' in bringing to a screeching halt Guei's presidential ambitions.

\section{The aftermath}

After desperately attempting to cling to power by force of arms, including by sequestering the electoral commission members and using the troops, General Guei was forced to flee the palace when it became evident that the military, both officers and rank and file had abandoned him en masse. ${ }^{77}$ This should not come as a surprise given the deep division in the military brought about by the political adventure and the conflicting agendas of various officers. After a few days, he acknowledged Laurent Gbagbo as the head of state, thereby closing the military regime interlude. In a surrealist media event, President Gbagbo traveled to meet General Guei in Yamoussokro to sign with him an agreement sponsored by common French friends. $^{78}$

Power was back in the hand of a civilian, but it was by no means democratic. Counter-intuitively, the new political dispensation did not even attempt to address the flawed civil-military relations, security sector arrangement, and the other factors that contributed to the coup in the first place. For one, it was under the newly constituted civilian regime that hundreds of people were massacred by security forces in Yopougon, a predominantly poor and northerner neighborhood in Abidjan. ${ }^{79}$ In the early days and weeks of the Gbagbo regime, dozens of opponents 
and nationals of Burkina Faso and Mali, Cote d'Ivoire's neighbor to the north, were tortured, raped, harassed, and imprisoned in various detention centers. While the failed transition can be blamed for some of these events, for most, it cannot. This is evidence of the prevalence of a dangerous culture in the security establishment that transcends any given regime. This culture was not addressed under the military junta, since the basis of its power was brutal force. It was not addressed by the Gbagbo regime either, since it too relied heavily on the same state coercive instruments to maintain and consolidate power. The mutiny and subsequent civil war were to confirm the worst fears many harbored.

\section{Hopes and yet another missed opportunity}

As the preceding demonstrates, if the coup was precipitated by the inept leadership, mismanagement and President Bedié's crass behavior, it brought to the surface and exacerbated the serious civil-military relations flaws, and political and social crises Côte d'Ivoire had been experiencing throughout nearly forty years of PDCI rule.

These were its root causes. The military intermission, supposed to prepare the transition to a truly democratic civilian regime did no such thing because of the equally deficient leadership of General Robert Guei, and his murderous will to retain power. Neither the Constitution nor policy initiatives addressed seriously any of the crises that help propel the military to power. The critical component of a democratic order, i.e. the civilian democratic control of the military institution and the security apparatus generally, its frameworks and basic features (including the presence and role of French military personnel) were not given the keen treatment they clearly deserved. Yet, these issues are critical to any democratic regime. Unless they were seriously addressed, the conditions that led to the various coup attempts and mutinies of the last years were bound to continue to exist, and along with them the risk of perpetually unstable civil-military relations and a crisis-laden security sector. This would continue to delay the country's and the entire West African region's move toward stability.

To his credit, Laurent Gbagbo organized the "National Reconciliation Forum" in which all protagonists in Ivoirian politics were given a podium to vent their various grievances and to push various agendas on the state. Under the able leadership of Mr. Seydou Elimane Diarra, a long time high level official and cabinet member under Houphouet-Boigny and Prime Minister under General Guei, this forum, modeled on the South African Truth and Reconciliation Commission, overcame many obstacles. The much-heralded forum allowed the airing, in a 
cathartic and therapeutic way, of painful events and taboos in an effort to exorcise the demons that seem to have taken over and poisoned the politics of the country. Not surprisingly, the nationality of Ouattara took center stage at the Forum, one of the conclusions of which was that he should be issued a nationality certificate. The Forum also allowed the airing of numerous other problems Ivory Coast has to address, including the issues of ethnicity, regionalism, land tenure, and prerequisites for national reconciliation. The Forum and other appeasing measures President Gbagbo shrewdly took definitely reduced the level of political tension and enabled the much needed resumption of economic dealing with France (which eagerly obliged), the EU and the IMF and World Bank. The only false note was the acquittal of suspected perpetrators of the massacre of Yopougon in which dozens (maybe hundreds) were executed by security forces as Gbagbo came to power. It soon became apparent that it was a mistake to underestimate the risk of breakdown by mistaking the reduction of tensions brought about mainly by symbolic measures and various international pressures for a stamping out of dangers of further destabilization.

To be sure, the lesson of the popular movement that chased General Guei from power was not likely to be lost on future civil-military relations. However, as the September 2002 events proved also, it was a grave mistake to overestimate its dissuasive effect, particularly when the various lingering crises described above worsened and another political impasse was in the making. More portentous, however, even as clouds gathered, was President Laurent Gbagbo's vexing inability to learn from the turbulent post-coup regime, and beyond, the deep flaws of the political systems and the security sector arrangement, his personal experience with both as a citizen and a political leader notwithstanding. Most disappointing with his tenure was what seemed to be his willingness to continue 'business as usual' in the security sector and civil-military relations singularly. There was no discernable evidence that he had questioned any fundamental underpinning of the security apparatus, its structure, practices, methods or undertaken any reform of a sector that had so profoundly destabilized the country and was about to do so again.

When he came to power after General Guei's debacle, Laurent Gbagbo had to his credit unquestioned political courage and acumen (mixed with troubling deceitfulness as General Guei lamented shortly before his death). However, he did not seem to measure the enormity of his task and the necessity to take advantage of the window of opportunity afforded him to carry out a far-reaching transformation of the political system whose defects he decried and fought for decades. In light of his record, he never was able to graduate to the stature of statesman. He remained stuck at the level of what can be labeled 'political adolescence' with a propensity to 


\section{1}

'play politics' in the most objectionable and reckless meaning of the phrase. Consequently, by September 2002, it was evident that Gbagbo and his government had missed yet another opportunity to give the country the means of transcending the legacy of seriously defective civil-military relations and political system generally. Without realizing it perhaps, Gbagbo was only perpetuating a dispiriting pattern of Ivoirian heads of state who invariably missed propitious opportunities to overhaul a system badly broken. Unsurprisingly, they all lived to see the devastating consequences of their turpitude.

\section{Still flirting with disaster}

This section can only offer a snapshot of the acute crisis that literally brought Ivory Coast and West Africa to the brink of disaster, since it is still unfolding, and its outcome most uncertain. When President Gbagbo, for selfserving reasons and under the pretense of reducing the cost of running the state had some military units slated for discharge, a simmering crisis boiled over into the fullblown national crisis with which Cote d'Ivoire is still grappling. On September 19, 2002, these units (and others) mutinied. Soon the mutiny/coup attempt became a rebellion with the occupation of the main northern cities of Korokho and Bouake. His was quickly followed by the occupation of other major cities and threats on the capital with the aim of ousting President Gbagbo.

There is no evidence that the late General Guei, who had recreated himself as an old-fashioned party leader, was personally implicated in the events. However, he had stated in an interview that all he needed was a telephone call to "burn Côte d'Ivoire down" if he so wished. ${ }^{80}$ He was assassinated at the beginning of rebellion, but his words proved prophetic since one of the rebel groups, the Movement pour la Justice et la Paix, claims to want to avenge his death. Many of the original mutinous soldiers later organized under a political movement, the Movement Patriotique de Côte d'Ivoire were allegedly recruited by him. This rebellion/civil war proved emphatically that indeed Ivory Coast was no 'miracle' as it rapidly threatened, because of its economic weight, as no other state in the region could, to pull Francophone West Africa into chaos. While through various channels the Economic Community of West African States (ECOWAS) endeavored frantically to resolve the conflict and circumscribe a potential regional war, in the end, it failed and its leaders had to face the embarrassment of leaving it to France to take the lead in pursuing a solution.

The crisis also revealed the state of decomposition of the FANCI (Forces Armées Nationales de Cote d'Ivoire), the Ivoirian military and the depth of the crisis 
of the security apparatus. The regular army and gendarmerie were losing many decisive battles against motivated rebellious units now joined by volunteers and conscripts from the North and West, and mercenaries. The numerous divisions injected in the military by political manipulation, 'ethnicization,' and later by the military regime interlude have now become even more pernicious and deadly. Furthermore, the Gbagbo government, which owed its survival to the rapid intervention of French troops and their interposition on an imposed line of ceasefire, was forced to recruit mercenaries and to bomb civilians indiscriminately undermining further its claim to legitimacy. This humiliated further the FANCI and complicated further the civil-military equation, making even more difficult the solution agreed to in the Marcoussis agreement to "restructure the defense and security forces" and "redesign a military that is attached to the republican values of integrity and morality". This clause of the agreement seems to confirm the central argument of this paper.

In addition, horrendous human rights abuses, including mass killings by dead squads, illustrated the depth of the political and social 'Ivoirian malaise'. Hundreds of thousands of West Africans living in the country as well as Ivoirian from the north were displaced internally or driven out of the country, often harassed and abused by the security forces, creating a humanitarian disaster. The Marcoussis and Accra agreements created the conditions of the beginning of national reconciliation, starting with a government of national reconciliation, the disarmament of armed groups and the creation of conditions conducive to open, free, and fair elections in October 2005 at the end of Gbagbo's term. The rebel groups joined the government headed by Seydou Diarra since March 23, 2003. On July $4^{\text {th }}$ the conflict was declared over, and an amnesty law was enacted on August 6, 2003.

Cote d'Ivoire seemed then to have escaped the breakdown experienced in Liberia or Sierra Leone, though many times it came close to replicating destruction and killings on an even larger scale. The situation remains precarious, and peace has not been achieved yet by any means as the November 2004 events illustrate. First, even as the process of negotiated solution to the conflict proceeds, both sides have continued efforts to procure armaments, though this seems to have been curtailed by United Nations Security Council resolution 1572 of November 15 that imposed an embargo on arms. Notably, the joint statement of the July 4th FANCI and the Forces Nouvelles (the coalesced rebel groups) ratifying the end of hostilities and calling on the political leadership to stop rearmament has not. While the top brass of the FANCI displays a conciliatory attitude, the extent to which this is widely shared is uncertain as the real sense of humiliation and resentment (expressed on various occasions) may yet resurface and deep divisions remain on how to 


\section{3}

proceed. The crisis has only increased the role of the military as indicated by the bizarre official ceremony on July $4^{\text {th }}$ in which Mathias Doué, then army Chief of Staff, all but in essence 'ordered' the civilian politicians to clean up their act.

Furthermore, President Gbagbo, supposed to be striped of most of his executive powers, (though he has since cunningly reclaimed and exercised them with a vengeance), while insisting on reconciliation, has always cultivated an ambiguous attitude regarding the Marcoussis and Accra process when aspects of the agreements do not suit him. So far he succeeded in frustrating all the demands of the Forces Nouvelles insisting that they disarm first. The resumption of fighting in November 2004 and the dramatic developments they led to, in addition to shining a bright light on the role of France in its former colony, brought a new twist to the civil-military equation. Another line of division within the armed forces, on the one hand, and between President Gbagbo and at least some elements of the military, came to the surface on what to do to end the stalemate. In the end hardliners, represented by Colonel Phillip Mangou (who seem to share ethnicity and regional origin) seem to have won out.

In the wake of the November fighting and disturbance in Abidjan, General Mathias Doué, a former member of the military junta, up to then Chief of General Staff, was replaced by Colonel Mangou because he was considered too close to the French military and less enthusiastic to resume fighting the rebels. Speculations about his ouster (and his subsequent disappearance) and its significance for the army and more generally for the likely development of the crisis have not abetted. Meanwhile, at the time of writing, Cote d'Ivoire is still experiencing a precarious situation marked by the absence of real progress toward a peaceful resolution of the crisis even as the fatidic October 2005 (the end of Gbagbo's term) is approaching. Though it is clearly at the core of the current political crisis as the analysis demonstrates, the enduring civil-military relations predicament will most likely continue to be overlooked.

\section{Conclusions}

This article has purported to chronicle and critically analyze the civilmilitary relations that have manifested in Ivory Coast since independence and the nefarious effects they have had on its body politic ever since. The discussion has focused on the set-up, major actors, characteristics, and defining moments in these relations, with the December 24, 1999 coup and its consequent current crisis gripping the country as the vivid illustrations of just how deeply flawed they have been. The analysis was guided by the widely accepted proposition that only 


\section{4}

democratic civilian control of the armed forces, which supposes a democratically elected, responsive and scrupulously respectful of the military's autonomy and professionalism, is likely to avoid breakdown in these relations. Such sound relations also preclude wanton interference of the civilian authority in the internal affairs of the military, its manipulation, and in general, the 'instrumentalization' of the military in the political arena, all of which contribute to the "coup vulnerability" concept.

It was contended that one of the constant features of Ivoirian politics since independence has been the willingness of the successive heads of state, using singularly deleterious devices, to manipulate, politicisize, and otherwise trample on the professionalism of the security apparatus to keep power. Their actions undermined the political system and divided the military, creating a propitious environment for the coup d'état and the rebellion, and complicating the prospects for a solution to the current crisis. Being prisoners of a more or less acute ethnoregional consciousness, they have consistently missed opportunities to recognize and attend to the flaws of the civil-military relations inherited and the danger this represented for the body politics. Belying persuasively the depiction of their country as a 'miracle' of sorts, all lived to suffer the consequences (often costly and tragic) of their shortsightedness. The role France was made to play in the overall architecture of civil-military relations and its long-term effect on the military's evolution was also underlined.

While, understandably, the priority now is to return the country to normalcy and eliminate the likelihood of a generalized, prolonged, and destructive civil war, the centrality of the security apparatus and its democratic control have never been as patent. This does not seem to be recognized emphatically enough in the various agreements and "road maps" which still see the process of disarmament, demobilisation and reintegration in isolation of the necessity to revamp the entire security apparatus and the political system. Cote d'Ivoire has become the epitome of the praetorian state where "social forces confront each other nakedly" - where no institution or organized body is granted the legitimacy for resolving conflicts, and armed violence carries the day. ${ }^{81}$ A clear lesson of this predicament other states can learn is to heed the advice African scholars of civil-military relations and practitioners have been insistently advocating recently: for African states to achieve overall good governance, it is imperative to overhaul entirely the security apparatus. ${ }^{82}$ Until this becomes a genuinely accepted wisdom, it is likely that harmonious and sound civil-military relations will continue to elude Ivory Coast for the foreseeable future as they have for nearly forty-five years already. 


\section{Notes and references}

${ }^{1}$ Eric Nordlinger, Soldiers in Politics: Military Coups and Governments, Englewood, N.J., Prentice Hall, 1976, 2. My emphasis.

${ }^{2}$ After numerous failed attempts by West African leaders to end the conflict, on January 15 , 2003, at the initiative of France, a meeting between the Ivoirian armed factions, political parties, and government took place in Marcoussis in the suburbs of Paris. The meeting concluded with an agreement to bring about national reconciliation and end the de facto partition of the country. It was followed by other agreements in Accra to hammer out contentious issues that surfaced with the implementation of the Marcoussis accord. These were never faithfully implemented. In November 2004, President Gbagbo ended the cease-fire in an ill-fated attempt to resolve the conflict militarily. On behalf of the African Union President Thabo Mbeki is still trying to bring a resolution to the crisis before Gbagbo's term ends in October 2005.

${ }^{3}$ This author met with other scholars on Cote d'Ivoire in December in New York to help, in conjunction with the UN, chart the most sensible way ahead after the breach in the ceasefire in October 2004.

${ }^{4}$ Claude Welch, Jr., (ed.), Civilian Control of the Military: Theory and Cases from Developing Countries, Albany, State University of New York Press, 1976, 324.

5 Boubacar N'Diaye, "Ivory Coast's Civilian Control Strategies 1961-1998: A Critical Assessment," Journal of Political and Military Sociology, 28 (2), 2001, 246-270.

${ }^{6}$ Boubacar N'Diaye, The Challenge of Institutionalizing Civilian Control, Lanham, MD., Lexington Books, 2001, 6-8.

${ }^{7}$ Samuel Huntington, The Soldier and State: The Theory and Politics of Civil-Military Relations, Cambridge, Harvard University Press, 1957; S.E. Finer, Man on Horseback, the Role of the Military in Politics, New York, Praeger, 1962; Welch, 1976; Kenneth Kemp and Charles Hudlin, "Civil Supremacy over the Military: Its Nature and Limits," Armed Forces and Society, 19 (1), 1994, 7-26.

${ }^{8}$ Eboe Hutchful, "Demilitarizing the Political Process in Africa: Some Basic Issues," African Security Review, 6 (2), 1997, 7-8.

${ }^{9}$ Rebecca Schiff, "Civil-Military Relations Reconsidered: A Theory of Concordance," Armed Forces and Society, 22, Fall 1995, 7-24.

${ }^{10}$ Euromonitor, The World Economic Factbook 1999/2000, Chippenham, Great Britain, 2000, 139.

${ }^{11}$ Yves Faure and J.F. Medard, Etat et Bourgeoisie en Cote d'Ivoire, Paris, Khartala, 1982, 2223.

${ }^{12}$ Aristide Zolberg, One Party Government in the Ivory Coast, Princeton, Princeton University Press, 1969, 265-271.

${ }^{13}$ Jeanne M. Toungara, "Generational Tensions in the Parti Démocratique de Cote d'Ivoire," African Studies Review, 38 (2), 1995, 32.

${ }^{14}$ Richard C. Crook, Cote d'Ivoire: Multi-party Democracy and Political Change, in John Wiseman (ed.), Democracy and Political Change in Sub-Saharan Africa, New York, Routledge, 1995, 13-17.

${ }^{15}$ Moshe Ammi-Oz, "La formation des Cadres Militaires Africains Lors de la Mise sur Pied des Armées Africaines," Revue Francaise d'Etudes Politiques Africaines, 133, 1977, 84-99.

${ }_{16}$ International Institute for Strategic Studies, The Military Balance 1999/2000, London, International Institute for Strategic Studies, 2000, 259.

${ }^{17}$ David Goldsworthy, "Armies and Politics in Civilian Regimes," in Simon Baynham (ed.), Military Power and Politics in Black Africa, London, Croom Helm, 1986, 182.

${ }^{18}$ Dominique Bangoura, Les Armées Africaines 1960-1990, Paris, Centre des Hautes Etudes sur L'Afrique et L'Asie Modernes, 1992, 25. 
${ }^{19}$ Pascal Chaigneau, La Politique Militaire de la France en Afrique, Paris, Le Centre Des Hautes Etudes sur L'Afrique et L'Asie Modernes, 1984, 27.

${ }^{20}$ John Chipman, French Power in Africa, Cambridge, Basil Blackwell Ltd., 1989, 119, 129.

21 Phillipe Gaillard, Foccart Parle: Entretiens avec Phillipe Gaillard, Vol. 1, Paris, Fayard/Jeune Afrique, 1995, 228.

${ }^{22}$ Danielle Domergue-Cloarec, La France et l'Afrique Apres les Independances, Paris, SEDES, 1994, 72.

${ }^{23}$ Chester Crocker, The Military Transfer of Power in Africa: A Comparative Study of Change in the British and French System of Order, Baltimore, A Ph.D. Dissertation, The Johns Hopkins University, Department of Political Science, 1969, 497-498.

${ }^{24}$ Samuel Decalo, "Modalities of Civil-Military Stability in Africa," Journal of Modern African Studies, 27 (4), 1989, 547-578; Chipman, 1989; Goldsworthy, 1986; Claude Welch, "Côte D'Ivoire: Personal Rule and Civilian Control," in Claude E. Welch (ed.), No Farewell to Arms?, Boulder, Westview, 1987, 172-194; Pascal Koffi Teya, Le roi Est Nu, Paris, L'Harmattan, 1985.

${ }^{25}$ Ruth First, The Barrel of a Gun: Political Power and the Coup d'État, London, Allen Lane, $1970,424$.

${ }^{26}$ Decalo, 1989, 575.

${ }^{27}$ International Institute for Strategic Studies, 2000, 259.

${ }^{28}$ Domergue-Cloarec, 1994, 74-76.

${ }^{29}$ Welch, 1987, 180-181.

${ }^{30}$ Teya, 1985, 86-87.

${ }^{31}$ Howard French, "The End of an Era," Africa Report, 39 (2), 1994, 21.

${ }^{32}$ Robin Luckham, "French Militarism in Africa," Review of African Political Economy, 24, 1982, 55-84; Domergue-Cloarec, 1994; Chipman, 1989.

${ }^{33}$ Welch, 1987, 182.

${ }^{34}$ Teya, 1984, 85 .

${ }^{35}$ Welch, 1987, 182.

${ }^{36}$ Welch, 1987, 181, 184.

${ }^{37}$ Welch, 1987, 180.

${ }^{38}$ Aristide Zolberg, One Party Government in the Ivory Coast, Princeton, Princeton University Press, 1969, 350

${ }^{39}$ Howard William, "The Crisis of Succession,” Africa Report, 33 (3), 1988, 54.

${ }^{40}$ Welch, 1987, 183; The Bete are the second largest ethnic group in Cote d'Ivoire. They have a long history of opposition to the regime perceived as dominated by the Baoule (the ethnic group to which Houphouet-Boigny and Konan Bedié belong). Laurent Gbagbo, the current President is a Bete.

${ }^{41}$ Florentin Kassy, "L’Adieu aux Armes," Jeune Afrique, 1885, 19-25 February, 1997, 32.

${ }^{42}$ Geraldine Faes and Elimane Fall, "Le Vrai-Faux Coup d’État du Général Guei," JeuneAfrique, 1817, 2-8 November, 1995, 16-19.

${ }^{43}$ Edouard Bustin, The Limits of French Intervention in Africa: A Study in Applied NeoColonialism, Boston, African Studies Center, 1982; Samir Amin, Neo-Colonialism in West Africa, New York, Monthly Review Press, 1973; Teya, 1984.

${ }_{44}^{44}$ Bustin, 1982, 13.

${ }^{45}$ Chipman, 1985, 24-25.

46 "Ten Years in French Speaking Africa," Africa Digest, 27 (5), 1970, 85-89; Africa Research Bulletin (Political and Social Series), June, 1973; Efrem Sigel, "Ivory Coast: Booming Economy, Political Calm," Africa Report, 15, 1970, 18-21; Welch, 1987, 180.

${ }^{47}$ Africa Research Bulletin, August 1991 and November 1996. 
${ }^{48}$ Africa Research Bulletin, June 1990; Kaye Whiteman, "The Gallic Paradox, " Africa Report, 36 (1), 1990, 17-19.

${ }^{49}$ Kassy, 1997, 31.

50 Africa Research Bulletin, May 1991, February 1992; Mark Huband, "Silencing the Opposition," Africa Report, 37 (3), 1992, 55-57.

${ }^{51}$ Welch, 1987, 180; William, 1988, 54.

52 "Power Struggle is Simmering in Ivory Coast," New York Times, December 9, 1993, A3, 3.

${ }^{53}$ Yves Faure, "Cote d'Ivoire: Analyzing the Crisis," in Donald Cruise O'Brien, John Dunn and Richard Rathbone (eds.), Contemporary West African States, Cambridge, Cambridge University Press, 1998, 59-73; Teya 1985; Toungara, 1995; William, 1988.

${ }^{54}$ William, 1988, 5 .

${ }^{55}$ George Ayyiteh, Africa Betrayed, New York, St. Martin's Press, 1992, 241-242; Gaillard, 1995 vol. 2, 286.

${ }^{56}$ Howard French, "No More Paternalism but Public Executions," New York Times, 15 May 1995, A4.

${ }^{57}$ Fall, 1991, 10.

${ }^{58}$ Amnesty International, Amnesty International Report, New York, Amnesty International Publications, 1997, 129.

${ }^{59}$ Statement to the press by General Guei, on December 26, 1999, reproduced in Fraternité Matin, 10556, December 27, 1999.

${ }^{60}$ Albert Bourgi, "Entre Militaires," Jeune-Afrique/L'Inteligent, 2066-2067, 15-28 August 2000, 34-39.

${ }^{61}$ See François Soudan, “Côte d'Ivoire: Ce qui n'a pas été Dit," Jeune-Afrique/L'Intelligent, 2036, 18-24 January 2000, 16-18.

${ }^{62}$ Statement to the press by General Guei, on December 26, 1999, reproduced in Fraternité Matin, 10556, December 27, 1999.

${ }^{63}$ Ibid.

${ }^{64}$ Arnaud de la Grange, "L'Afrique Doit se Gendarmer Seule," Le Figaro, October, 1997, 4C.

${ }^{65}$ Robin Luckham, "Taming the Monster: Democratization and Demilitarization," in Eboe Hutchful and Abdoulaye Bathily, (eds.), The Military and Militarism in Africa, Dakar, CODESRIA, 1998, 589-598.

66 "Ivoirité" can be roughly translated as 'Ivoiri-ness,' or 'being Ivoirian'. It refers to 'all that make one a pure Ivoirian' to distinguish him or her from 'foreigners' who make up more than one third of those who inhabit Cote d'Ivoire. It is an ideology concocted by President Konan Bedié with the help of some intellectuals after he prevailed over Prime Minister Alassane Dramane Ouattara in an intense behind the scenes struggle to succeed Houphouet-Boigny in 1993. It was used in 1995 to exclude Ouattara from elected office, and disenfranchise many of his Northern Muslim supporters under the pretext that they are not truly Ivoirians. It turned out to be a singularly divisive and pernicious notion that led the country to its current predicament.

${ }^{67}$ N'Diaye, 2001, 161.

${ }^{68}$ Francis Kpatindé, “l’Élephant Malade,” Jeune-Afrique/l'Intelligent, 2061, 11-17 July 2000, 8-11.

${ }^{69}$ Ibid.

${ }^{70}$ See "Cher Robert" ("Dear Robert"), Jeune-Afrique/l'Intelligent, 2075, 17-23 October, 2000, $22-23$

${ }^{71}$ See "Strange Case of Two Generals," West Africa, 26 March - 1 April, 2001, 18-19.

${ }^{72}$ See Zyad Limam, "LA Guerre des Chefs," Jeune-Afrique/L'Intelligent, 2060, 4-10 July, 2000, 8-10.

${ }^{73}$ See "Cher Robert," 2000, 18.

${ }^{74}$ See also Jonathan Derrick, "No Way Ouattara," West Africa, 31 July - 7 August 2000, 20-21. 
${ }^{75}$ Francis Kpatindé, “Les Jeux Sont Faits,” Jeune-Afrique/L'Intelligent, 2074, 10-16 October, 2000, 16-18.

${ }^{76}$ See Cersko Omunizua, "Hovering on the Brink," West Africa, 2 - 8 October, 2000, 20-21.

${ }^{77}$ For a chronological account of the events that led to Guei's ouster see Albert Bourgi's "J'ai Vu l'Histoire Baculer," Jeune-Afrique/L'Intelligent, 2078, 7-13 November, 2000, 20-28; also Cersko Omunizua, "Chaos in Adbidjan," West Africa, 30 October - 5 November, 2000, 9-12.

${ }^{78}$ Francis Kpatindé, “Guei-Gbagbo: Les Secrets d'une Rencontre,” Jeune-Afrique/L'Intelligent, 2080, 21-27 November, 18-21.

${ }^{79}$ See Assou Massou, “Abidjan en Etat de Choc,” Jeune-Afrique/L'Intelligent, 2097, 7-13, 2000, 32-33.

${ }^{80}$ François Soudan, “Que Veut Guei?,” Jeune-Afrique/L'Intelligent, 2097, 20 March 2001, 2425 .

${ }^{81}$ Samuel Huntington, The Political Order in Changing Societies, New Haven, Yale University Press, 1968, 20.

${ }^{82}$ A flurry of recent publications have made this point. These include Nicole Ball and 'Kayode Fayemi, Security Sector Governance in Africa: A Handbook, London, Center for Democracy and Development, 2004; Anicia Lala and Ann M. Fitz-Gerald, (eds.), Providing Security for People, London, Global Facilitation Network, 2003; Boubacar N'Diaye et al., "Not Yet Democracy: West Africa's Slow Farewell to Authoritarianism, Durham, Carolina Academic Press, 2005. Alan Bryden and Heiner Hänggi, (eds.), Reform and Reconstruction of the Security Sector, Geneva, Lit Verlag Münter, 2004. 